\title{
Administrative Absurdity: Why the Judiciary Should Uphold EPA's Use of the Administrative Necessity and Absurd Results Doctrines Within the Tailoring Rule
}

\author{
DAVID P. VINCENT*
}

TABLE OF CONTENTS

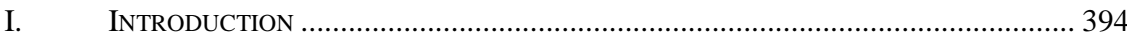

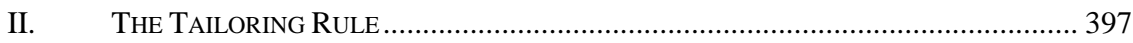

III. EPA's LEGAL JUSTIFICATION FOR CREATION AND

IMPLEMENTATION OF THE TAILORING RULE ..................................................... 400

A. Chevron Deference and the Absurd Results Doctrine .............................. 400

B. The Administrative Necessity Doctrine .................................................. 402

IV. The Judiciary SHOUld VAlidate EPA's USE OF THE ABSURD

RESUlts AND ADMINISTRATIVE NECESSITY DOCTRINES IN ITS

TAILORING RULE

A. The Use of the Absurd Results and Administrative

Necessity Doctrines Within the Tailoring Rule

1. The Validity of EPA's Interpretation of the Absurd

Results Doctrine.

a. Application of the Absurd Results Doctrine for the PSD Program

* J.D. candidate, University of San Diego School of Law, expected graduation May 2012; B.A. Political Science and Psychology, University of California, San Diego. For conversations, comments, and confidence, thanks to Professor Lesley K. McAllister. For advice and comments, thanks to Sara S. Kendall, Vice President, Environment, Health and Safety at Weyerhaeuser Corporation. In addition, thanks to Janet Chen and Dan Hua for their thoughtful editorial guidance. 


\section{INTRODUCTION}

In the absence of major climate legislation in the U.S. Senate, parties seeking meaningful action on climate change mitigation have turned to the U.S. Environmental Protection Agency ("EPA") for action. EPA's augmented authority to deal with substantive aspects of climate change mitigation, and ultimately its creation of the Tailoring Rule, stems from the 2007 Supreme Court decision in Massachusetts v. EPA. ${ }^{1}$ In this watershed decision, the Court found greenhouse gases ("GHGs"), including carbon dioxide, to be "air pollutants" as defined and regulated by the Clean Air Act ("CAA"). ${ }^{2}$ The Court ruled that the Act required EPA to determine whether GHG emissions from new motor vehicles cause or contribute to air pollution that may endanger public health or welfare, or whether the science is too uncertain to make a reasoned decision. $^{3}$ In April 2009, EPA responded to the Court by announcing a finding, which affirmatively concluded that GHGs contribute to air pollution that may endanger public health or welfare. ${ }^{4}$

The next key piece within the regulatory framework that shaped EPA's Tailoring Rule involves a memorandum entitled “EPA's Interpretation of Regulations that Determine Pollutants Covered by Federal Prevention of Significant Deterioration (PSD) Permit Program" ("PSD Interpretive Memo"). ${ }^{5}$ The PSD Interpretive Memo was issued in December 2008 - in the final days of the Agency's leadership by thenEPA Administrator Stephen L. Johnson. ${ }^{6}$ The memorandum illustrated the process by which a previously unregulated pollutant could become

1. See, e.g., Greg Wannier, Case Analysis: Texas Moves to Block EPA Climate Regulations, ClimAte L. BlOG (Sept. 25, 2010), http://blogs.law.columbia.edu/climate change/2010/09/25/texas-moves-to-block-epa-climate-regulations/.

2. See Clean Air Act § 202(a)(1), 42 U.S.C. § 7521(a)(1) (2006); Massachusetts v. EPA, 549 U.S. 497 (2007).

3. Prevention of Significant Deterioration and Title V Greenhouse Gas Tailoring Rule, 75 Fed. Reg. 31,514, 31,575 (June 3, 2010) [hereinafter Final Tailoring Rule] (to be codified at 40 C.F.R. pts. 51, 52, 70, and 71).

4. Final Tailoring Rule, supra note 3, at 31,575.

5. Id.

6. Memorandum from Stephen L. Johnson, Adm'r, EPA, to Reg'l Adm'rs, EPA (Dec. 18, 2008), available at http://www.epa.gov/NSR/documents/psd_interpretive_ memo_12.18.08.pdf [hereinafter PSD Interpretive Memo]. 
subject to regulation, and consequently, dependent on PSD and Title V stationary source permitting requirements. ${ }^{7}$ This memorandum was vital to EPA's attempt to lay the framework that would later allow the Agency to regulate GHGs through the Tailoring Rule. ${ }^{8}$ Whether a pollutant is "subject to regulation" is important for the purposes of determining whether it is covered under the CAA permitting programs. ${ }^{9}$ "The [PSD] Interpretive Memo established that a pollutant is 'subject to regulation' only if it is subject to either a provision in the CAA or a regulation adopted by EPA under the CAA that requires actual control of emissions of that pollutant (referred to as the 'actual control interpretation')."10

EPA later granted a petition for reconsideration of this memorandum, but subsequent Administrator Lisa P. Jackson signed a notice in February 2009 that conveyed the Agency's decision to continue applying the PSD Interpretive Memo's interpretation of "subject to regulation.""11 Based on the contemporaneous Light-Duty Vehicle Rule ("LDVR"), the notice stated that the GHG requirements of LDVR would trigger CAA permitting requirements for stationary sources on January 2, 2011. ${ }^{12}$

The following steps in the regulatory history of the Tailoring Rule were two findings issued by EPA Administrator Jackson in December 2009. ${ }^{13}$ First, the Administrator issued an "Endangerment Finding" that the current and projected atmospheric concentrations of six GHG pollutants ${ }^{14}$ "threaten the public health and welfare of current and future generations." 15 Second, and subsequently, the Administrator issued a "Cause or Contribute Finding," which determined that "the combined

7. See Final Tailoring Rule, supra note 3, at 31,521.

8. See generally Final Tailoring Rule, supra note 3.

9. 9 VA. ADMIN. CODE § 5-85, at 1 (2011), available at http://www.deq.state.va. us/air/pdf/airregs/8500.pdf.

10. Final Tailoring Rule, supra note 3, at 31,521.

11. Id.

12. Id.

13. Endangerment and Cause or Contribute Findings for Greenhouse Gases Under Section 202(a) of the Clean Air Act, EPA, http://www.epa.gov/climatechange/ endangerment.html (last updated Sept. 21, 2011).

14. Carbon dioxide (" $\mathrm{CO}_{2}$ "), methane (" $\mathrm{CH}_{4}$ ”), nitrous oxide (" $\mathrm{N}_{2} \mathrm{O}$ ”), hydrofluorocarbons ("HFCs"), perfluorocarbons ("PFCs"), and sulfur hexafluoride ("SF6").

15. Endangerment and Cause or Contribute Findings for Greenhouse Gases Under Section 202(a) of the Clean Air Act, supra note 13; Lynn L. Bergeson, EPA Issues Final "Tailoring" GHG Permitting Rule, ACTA GROUP, L.L.C. (Aug. 2010), available at http://www.actagroup.com/other_pdfs/00066449.PDF. 
emissions of these well-mixed greenhouse gases from new motor vehicles and ... engines contribute to the greenhouse gas pollution which threatens public health and welfare." 16 While these findings imposed no new requirements, they were a prerequisite to finalizing the GHG standards for light-duty vehicles under LDVR. ${ }^{17}$

The confluence of these events gave EPA the authority to regulate GHG emissions under the PSD and Title V stationary source permitting programs. ${ }^{18}$ However, regulation under the Act poses some complexities for EPA. The Act's current thresholds for regulating “criteria pollutants," congressionally-defined pollutants that endanger public health and the environment, such as lead, sulfur dioxide, and nitrogen dioxide, are 100 or 250 tons per year ("tpy"). ${ }^{19}$ While such a level is appropriate for the existing criteria pollutants, the applicability criteria requires tailoring as GHG are emitted at a scale that dwarfs the emissions of the conventional criteria pollutants. ${ }^{20}$ For that reason, the Tailoring Rule is imperative; without it, PSD and Title V requirements would have applied, as of January 2, 2011, to the emission of GHG at the $100 / 250$ tpy levels presently provided under the CAA. ${ }^{21}$ That is problematic as it would greatly increase the number of required permits, impose undue costs on small sources, overwhelm the limited resources of permitting authorities, and severely impair the functioning of the permitting programs. ${ }^{22}$

In the months following EPA's release of the Tailoring Rule, a number of states, organizations, and industry groups issued legal challenges to EPA's proposed action. ${ }^{23}$ Many of the legal challenges concerning the Tailoring Rule, including one by the State of Texas, challenge EPA's reliance on the legal doctrines of "absurd results" and "administrative

16. Endangerment and Cause or Contribute Findings for Greenhouse Gases Under Section 202(a) of the Clean Air Act, supra note 13.

17. Final Tailoring Rule, supra note 3, at 31,519.

18. Id.

19. Fact Sheet-Proposed Rule: Prevention of Significant Deterioration and Title V Greenhouse Gas Tailoring Rule, EPA, http://www.epa.gov/NSR/fs20090930action. html (last updated July 22, 2011).

20. Don J. Frost, Jr., Henry C. Eisenberg, William L. Thomas \& Kenneth Berlin, EPA Finalizes Greenhouse Gas Tailoring Rule, SKADDEN, http://www.skadden.com/ Index.cfm?contentID=51\&itemID=2087 (last visited Oct. 22, 2010).

21. Final Tailoring Rule, supra note 3, at 31,516.

22. Id. at 31,514.

23. Robin Bravender, EPA Issues Final 'Tailoring' Rule for Greenhouse Gas Emissions, N.Y. TIMES (May 13, 2010), http://www.nytimes.com/gwire/2010/05/13/13 greenwire-epa-issues-final-tailoring-rule-for-greenhouse-32021.html. 
necessity." 24 This Comment analyzes the strengths and weaknesses of the arguments advanced by EPA as well as its opponents regarding the Agency's reliance on these administrative law doctrines to "tailor" PSD and Title V applicability criteria. The Comment concludes with an explanation of why the judiciary will likely rule in EPA's favor in this instance.

Part I of this Comment introduces the Tailoring Rule, including its background and the emissions thresholds it seeks to implement regarding PSD and Title V programs. Part II presents EPA's legal basis for the creation and subsequent implementation of the Tailoring Rule, including the concept of Chevron deference, the absurd results doctrine, as well as the administrative necessity doctrine and the doctrines' applications to and within the Tailoring Rule. Part III addresses some of the legal challenges of the Tailoring Rule, with a focus on the state of Texas's arguments and the strength and weaknesses of these challenges. Part III also argues that the judiciary should endorse EPA's use of the absurd results and administrative necessity doctrines and sanction the Tailoring Rule based on the legal argument that the decision to issue and implement the rule was subject to Chevron deference. Part IV concludes with a summary of the legal arguments proposed throughout the Comment.

\section{THE TAILORING RULE}

In May 2010, EPA released the final version of the "Prevention of Significant Deterioration and Title V Greenhouse Gas Tailoring Rule” ("Tailoring Rule") in what was the agency's first concerted attempt to regulate GHGs from stationary sources. ${ }^{25}$ In this rulemaking, EPA modified the applicability criteria that determine which stationary sources and modification projects are subject to permitting requirements for GHG emissions under the PSD and Title V programs of the CAA. ${ }^{26}$

Under this tailoring approach, GHG regulation will apply only to new facilities with the potential to emit ("PTE") 100,000 tpy or more and modifications at existing facilities that increase GHG emissions by at

24. State of Texas' Motion for a Stay of EPA's Greenhouse Gas Tailoring Rule, ATTN'Y GEN. OF TX. (Sept. 15, 2010), available at https://www.oag.state.tx.us/newspubs/ releases/2010/091610motion_to_stay_tailoring.pdf.

25. Bravender, supra note 23; see also EPA New Source Review Regulatory Actions, EPA, http://www.epa.gov/NSR/actions.html\#2010 (last visited Nov. 13, 2010).

26. Final Tailoring Rule, supra note 3, at 31,514. 
least 75,000 tpy-rather than the 250 and 100 tpy levels, respectively, for traditional pollutants under the CAA. ${ }^{27}$ Sources emitting less than 50,000 tpy and that refrain from modifications resulting in net GHG increases of more than 50,000 tpy $\mathrm{CO}_{2} \mathrm{e}$ ("carbon dioxide equivalent") will not be subject to PSD or Title V permitting until April 30, 2016.28 This decision was made in light of the finding that the administrative burdens accompanying permitting sources below this level would be so great that neither streamlining actions nor hiring additional administrative staff would remedy the condition before the date of implementation. ${ }^{29}$

Under the provisions of the CAA, excluding from consideration the conditions of the Tailoring Rule, sources that have PTE 250 tpy or more of regulated air pollutants, or 100 tpy or more if a source belongs to a list of 28 specified source categories, are deemed "major sources" for purposes of the federal PSD program. ${ }^{30}$ A major source or any source proposing new construction must conduct a Best Available Control Technology ("BACT") analysis. ${ }^{31}$ The source must undertake a BACT analysis for not only pollutants with a PTE over the major source threshold, but also for all pollutants subject to regulation that have PTE over a specified emissions threshold - an amount deemed the "significance level." 32 If any modification to a major source is proposed, a PSD permit will be required if the modification results in a net increase in emissions equal to or in excess of the significance level of any pollutant subject to regulation. ${ }^{33}$

In contrast, the Title $\mathrm{V}$ operating permit program generally applies to sources that have PTE of at least 100 tpy of air pollutants subject to regulation under the CAA. ${ }^{34}$ A facility subject to the Title V program has one year from the time that it first becomes subject to the program to submit a permit application. ${ }^{35}$

Given these low applicability thresholds under the PSD and Title V program, regulating GHGs without the mitigation of the Tailoring Rule would produce a number of significant problems. ${ }^{36}$

27. Id. at 31,516 .

28. Id.

29. Id.

30. See 42 U.S.C. § 7479 (2011).

31. Final Tailoring Rule, supra note 3, at 31,520.

32. Frost, Jr. et al., supra note 20; see also Public Participation: Permits, EPA, http://www.epa.gov/region9/air/permit/psd-public-part.html (last visited Oct. 28, 2010).

33. Frost, Jr. et al., supra note 20.

34. Id.

35. Id.

36. See generally Final Tailoring Rule, supra note 3, at 31,516. 
It is not too much to say that applying PSD requirements literally to GHG sources at the present time-in the absence of streamlining or increasing permitting authority resources and without tailoring the definition of "major emitting facility" or "modification" - would result in a program that would have been unrecognizable to the Congress that designed PSD. 37

It was the intent of Congress that PSD be "limited to a relatively small number of large industrial sources." ${ }^{38}$ EPA estimated that the number of sources that would require PSD permits each year based on the existing CAA thresholds would increase from approximately 280 permits currently to 82,000 permits each year. ${ }^{39}$ A significant percentage of these permits would be required in connection with modifications for commercial and residential projects, ${ }^{40}$ sources that prior to the enactment of the Tailoring Rule were largely not subject to federal regulation. ${ }^{41}$ EPA also estimates that Title $\mathrm{V}$ permits would be required for over 6 million sources without implementation of the mitigating effects of the Tailoring Rule compared to the 14,700 sources previously subject. ${ }^{42}$

Cognizant of this administrative burden, EPA subsequently revised its estimate of the average permit processing time for PSD and Title V permits. ${ }^{43}$ Without an expansion of regulatory resources to process the permits, PSD permit processing would increase to three years and Title V permits would take, on average, about ten years to process. ${ }^{44}$ The costs of such an expansive program would certainly be immense. For example, EPA estimates that the total nationwide additional burden for permitting authorities for Title V permits from adding GHG emissions at the 100 tpy threshold without the Tailoring Rule would be 340 million hoursa cost of over $\$ 15$ billion. ${ }^{45}$ Such information only helps to underscore the viability of EPA's use of the doctrines of absurd results and administrative necessity - a point this Comment will address in Part III. ${ }^{46}$

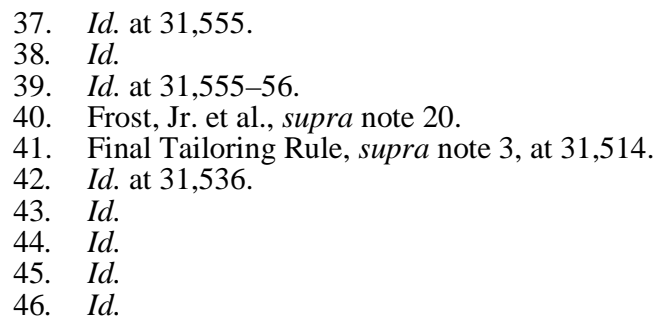




\section{EPA'S LEGAL JUSTIFICATION FOR CREATION AND IMPLEMENTATION OF THE TAILORING RULE}

\section{A. Chevron Deference and the Absurd Results Doctrine}

The doctrine of "Chevron deference" stems from the 1984 Supreme Court case, Chevron U.S.A. Inc. v. Natural Resources Defense Council. ${ }^{47}$ Chevron deference is an administrative law doctrine that implicitly extends the power delegated to federal administrative agencies by holding that courts must defer to reasonable agency interpretations of ambiguous statutes. ${ }^{48}$ Aside from being a canon of administrative law, it also provides much of the support for EPA's interpretation of the PSD and Title $\mathrm{V}$ applicability provisions and reliance on the absurd results and administrative necessity doctrine.

When parties aggrieved by a federal government agency's interpretation of a statute or regulation seek judicial review, ${ }^{49}$ reviewing courts typically apply the Chevron doctrine ${ }^{50}$ and defer to the agency's interpretation so long as it is reasonable and not contrary to the statutory or regulatory text. ${ }^{51}$ Chevron establishes a two-step framework for assessing an agency's interpretation of a statute. ${ }^{52}$ The court asks at Step One whether Congress has spoken directly to the precise question at issue: "If the intent of Congress is clear, that is the end of the matter; for the court as well as the agency must give effect to the unambiguously expressed intent of Congress." "53 At this initial stage of the analysis, the administrative agency's position receives no deference. ${ }^{54}$ If the statute does not unambiguously

47. Chevron U.S.A. Inc. v. NRDC, 467 U.S. 837, 842-43 (1984).

48. David M. Gossett, Chevron, Take Two: Deference to Revised Agency Interpretations of Statutes, 64 U. CHI. L. REV. 681, 681 (1997).

49. The judicial review chapter of the Administrative Procedure Act, 5 U.S.C. $\S \S 701-706$, provides the ordinary means for obtaining judicial review of federal agency action in the absence of a more specific statutory review provision. See 5 U.S.C. § 703 (2006). Congress may by statute place agency action beyond judicial review, 5 U.S.C. $\S 701(a)(1)$ (2006), subject to arguable but ill-defined constitutional limitations on the legislative power to circumscribe judicial authority. See Nicholas Q. Rosenkranz, Federal Rules of Statutory Interpretation, 115 HARV. L. REV. 2085, 2129-30 (2002). Nevertheless, there is ordinarily a presumption in favor of judicial review of agency action. See Gutierrez de Martinez v. Lamagno, 515 U.S. 417, 424-45 (1995).

50. See Chevron, 467 U.S. 837.

51. Timothy K. Armstrong, Chevron Deference and Agency Self-Interest, 13 CoRNELL J.L. \& PUB. POL'Y 203, 204 (2004).

52. Id.

53. Id.; Chevron, 467 U.S. at 842-43; see also INS v. St. Cyr, 533 U.S. 289, 320 n.45 (2001) ("We only defer, however, to agency interpretations of statutes that, applying the normal 'tools of statutory construction,' are ambiguous.”).

54. Armstrong, supra note 51, at 204 n.3; see e.g., Bank of America, N.A. v. FDIC, 244 F.3d 1309, 1319 (11th Cir. 2001) ("courts should decide whether there is ambiguity in a statute without regard to an agency's prior, or current, interpretation”); Vulcan Arbor Hill 
resolve the issue, the court proceeds to the second, more deferential, step of the analysis. ${ }^{55}$ At Step Two, the agency's interpretation will be upheld so long as it is reasonable. ${ }^{56}$ According to the Court in Chevron, "agencies should interpret ambiguous statutes because they bring more expertise to bear on such questions, because they are politically accountable, and because Congress, by leaving a statute ambiguous, has delegated interstitial policy-making to the agencies." 57 In interpreting a statutory provision, an agency must, under Chevron Step One, determine whether Congress's intent on a particular question is clear. ${ }^{58}$ If Congressional intent is clear, then the agency must comply. ${ }^{59}$ If the intent of the provision is not clear, then the agency may, under Step Two, fashion a reasonable interpretation of the provision. ${ }^{60}$

The best indication of Congress's intent is the plain meaning of the statute. $^{61}$ The Supreme Court, however, has held in the case of United States v. Ron Pair Enterprises that the literal meaning of a statutory provision is not conclusive "in the "rare cases [in which] the literal application of a statute will produce a result demonstrably at odds with the intentions of the drafters." 62 Instead, "[i]n such cases, the intention of the drafters, rather than the strict language, controls."63 This legal precept has been discussed and implemented for hundreds of years; ${ }^{64}$ it

Corp. v. Reich, 81 F.3d 1110, 1127 n.14 (D.C. Cir. 1996) (Henderson, J., dissenting) ("An agency assertion of ambiguity does nothing to establish that the statute is in fact ambiguous”); Cajun Elec. Power Corp. v. FERC, 924 F.2d 1132, 1136 (D.C. Cir. 1991) (holding that agency receives no deference on the question of whether the statute is ambiguous); Rettig v. Pension Benefit Guar. Corp., 744 F.2d 133, 141 (D.C. Cir. 1984); cf. Arizona v. Thompson, 281 F.3d 248, 253-54 (D.C. Cir. 2002) (holding that agency erred in concluding the statute was unambiguous; agency's resulting interpretation did not rest upon exercise of its interpretive discretion and thus warranted no deference from court); American Petroleum Inst. v. EPA, 906 F.2d 729, 740-42 (D.C. Cir. 1990) (per curiam) (holding same).

55. Armstrong, supra note 51, at 204 n.3.

56. Id. See also Chevron, 467 U.S. at 843-45.

57. Gossett, supra note 48 , at 681 .

58. Chevron, 467 U.S. at 842-43.

59. Id.

60. Id.

61. Final Tailoring Rule, supra note 3, at 31,542.

62. Id.; United States v. Ron Pair Enters., 489 U.S. 235, 242 (1989).

63. Ron Pair Enters., 489 U.S. at 242.

64. See Blackstone, Commentaries *63, *91; see also Riggs v. Palmer, 22 N.E. 188, 189-90 (N.Y. 1889). 
was well recognized in the time of William Blackstone and came to be known as the "Golden Rule" of interpretation. ${ }^{65}$

The absurd results doctrine continues to be of importance and interest to modern lawyers, judges, and legal commentators. ${ }^{66}$ For the most part, even textualist judges and commentators relax their general commitment to text in applicable situations. For example, both Justice Antonin Scalia ${ }^{67}$ and Judge Frank Easterbrook ${ }^{68}$ have endorsed the doctrine in the face of absurdity. In the implementation of the Tailoring Rule, EPA aspires to use the absurd results doctrine to justify its departure from the literal application of the CAA with regard to GHG emissions.

\section{B. The Administrative Necessity Doctrine}

Under the administrative necessity doctrine, if an unambiguous statutory provision is impossible for the agency to administer, then the agency is not required to follow the literal requirements. ${ }^{69}$ Instead, the agency may adjust the requirements in as refined a manner as possible to assure that the requirements are administrable while still achieving Congress's overall intent. ${ }^{70}$ The United States Court of Appeals for the District of Columbia Circuit set out the doctrine of administrative necessity in a line of cases that most prominently includes Alabama Power Co. v. Costle. ${ }^{71}$

As stated in the Tailoring Rule, "[EPA] believe[s] that the 'administrative necessity' case law establishes a three-step process under which an administrative agency may, under the appropriate circumstances, in effect revise statutory requirements that the agency demonstrates are impossible to administer so that they are administrable."72 Specifically:

65. William D. Popkin, Materials on Legislation: Political Language and THE Political Process 31-32 (5th ed. 2009).

66. See e.g., Veronica M. Dougherty, Absurdity and the Limits of Literalism: Defining the Absurd Result Principle in Statutory Interpretation, 44 AM. U. L. REV. 127 (1994); Andrew S. Gold, Absurd Results, Scrivener's Errors, and Statutory Interpretation, 75 U. Cin. L. REV. 25 (2006).

67. See e.g., City of Columbus v. Ours Garage \& Wrecking Serv., Inc., 536 U.S. 424, 451 n.4 (2002) (Scalia, J., dissenting); Green v. Bock Laundry Mach. Co., 490 U.S. 504, 527 (1989) (Scalia, J., concurring); INS v. Cardoza-Fonseca, 480 U.S. 421, 452 (1987) (Scalia, J., concurring).

68. See e.g., United States v. Seaboard Sur. Co., 236 F.3d 883, 885 (7th Cir. 2001); Kerr v. Puckett, 138 F.3d 321, 323 (7th Cir. 1998).

69. Final Tailoring Rule, supra note 3, at 31,543.

70. Id.

71. Id.

72. Id. at $31,543-44$. 
[T] he three steps are as follows: When an agency has identified what it believes may be insurmountable burdens in administering a statutory requirement, the first step the agency must take is to evaluate how it could streamline administration as much as possible, while remaining within the confines of the statutory requirements. The second step is that the agency must determine whether it can justifiably conclude that even after whatever streamlining of administration of statutory requirements (consistent with those statutory requirements) it conducts, the remaining administrative tasks are impossible for the agency because they are beyond its resources, e.g., beyond the capacities of its personnel and funding. If the agency concludes with justification that it would be impossible to administer the statutory requirements, as streamlined, then the agency may take the third step, which is to phase in or otherwise adjust the requirements so that they are administrable. However, the agency must do so in a manner that is as refined as possible so that the agency may continue to implement as fully as possible Congressional intent. ${ }^{73}$

Both the doctrines of absurd results and administrative necessity play important roles in the arguments and justifications both EPA and its challengers mount in their legal positions. In Part IV of this Comment, the legal arguments of both sides will be articulated and analyzed, and a conclusion on the totality of litigation will be reached.

\section{THE JUdiCIARY SHOULD VALIDATE EPA's USE OF THE ABSURD RESULTS AND ADMINISTRATIVE NECESSITY DOCTRINES IN ITS TAILORING RULE}

\section{A. The Use of the Absurd Results and Administrative Necessity Doctrines Within the Tailoring Rule}

Tested precedent justifies EPA's reliance on the doctrines of absurd results and administrative necessity; however, many believe that EPA has misconstrued the application of these legal doctrines. ${ }^{74}$ The rule currently faces challenges by parties ranging from the National Mining Association to the Sierra Club. ${ }^{75}$ Certainly, these groups come with diverse motives, ${ }^{76}$ but this only serves to illustrate the controversy surrounding the use and interpretation of these legal doctrines.

73. Greenhouse Gas Proposed Tailoring Rule, 74 Fed. Reg. 55,292, 55,315 (Oct. 27, 2009) [hereinafter Proposed Tailoring Rule].

74. Robin Bravender, Sierra Club, States File Challenges to EPA's 'Tailoring' Rule for Greenhouse Gases, N.Y. TIMES (Aug. 3, 2010), http://www.nytimes.com/gwire/ 2010/08/03/03greenwire-sierra-club-states-file-challenges-to-epas-tai-24900.html.

75. Id.

76. Id. 
One of the most recent major challenges to EPA's Tailoring Rule comes from the State of Texas, where on September 16, 2010, the state attorney general filed a lawsuit in the D.C. Circuit to prevent its implementation. ${ }^{77}$ In its case, the State of Texas makes two legal arguments. ${ }^{78}$ First, the state argues that EPA may not employ the absurd results doctrine to rewrite a perfectly unambiguous statute. ${ }^{79}$ Secondly, Texas argues that the administrative necessity doctrine does not justify the Tailoring Rule's inconsistency with the CAA. ${ }^{80}$

\section{The Validity of EPA's Interpretation of the Absurd Results Doctrine}

EPA believes Congress did intend that PSD and Title V apply to GHG sources as a general matter. ${ }^{81}$ To that end, EPA operates the tailoring approach by applying PSD and Title V to GHG sources, but in a phasedin manner. EPA's operates the Tailoring Rule under two different and independent legal bases. First, under Chevron Step One, that congressional intent is clear on that issue and the tailoring approach best reflects it. Second, in the alternative, under Chevron Step Two, that congressional intent is unclear and the tailoring approach is a reasonable interpretation of the statute. ${ }^{82}$

Texas argues that EPA does not have the authority to apply the absurd results doctrine to alter an explicit statute. ${ }^{83}$ Instead of regulating all "major sources" as required by the CAA, the Tailoring Rule would only

77. Texas Files Legal Action to Block Imposition of EPA Regulations That Threaten Texas Jobs, TEX. ATT’Y GEN., http://www.oag.state.tx.us/oagnews/release.php ?id=3484 (last visited Aug. 28, 2010). In filing this lawsuit, the Governor of Texas stated his belief that the Tailoring Rule is "arbitrary and capricious and is contrary to the Clean Air Act." Gabriel Nelson, Texas Joins Challengers to EPA's Greenhouse Gas 'Tailoring' Rule, N.Y. TIMES (Aug. 5, 2010), http://www.nytimes.com/gwire/2010/08/ 05/05greenwire-texas-joins-challengers-to-epas-greenhouse-gas-25612.html. Pending the resolution of its case by the D.C. Circuit, the State of Texas asked for a stay pending the Court's review. Id. Texas argued that EPA's scheduled implementation of the Tailoring Rule "is unlawful and will cause the state of Texas immediate and irreparable harm, without countervailing benefit to third parties or to the public interest." Bergeson, supra note 15; PSD Interpretive Memo, supra note 6, at 8. The Circuit Court ordered, on December 10, 2010, that the motions to stay be denied, writing, "Petitioners have not satisfied the stringent standards required for a stay pending court review." Associated Press, Texas: Court Allows E.P.A. to Issue Greenhouse Permits, N.Y. TimEs (Jan. 13, 2011), http://www.nytimes.com/2011/01/13/us/13brfs-COURTALLOWSE_BRF.html?_r=1.

78. Texas Files Legal Action to Block Imposition of EPA Regulations That Threaten Texas Jobs, supra note 77.

79. Id.

80. Id.

81. Final Tailoring Rule, supra note 3, at 31,516.

82. Id.

83. Bergeson, supra note 15; PSD Interpretive Memo, supra note 6, at 8. 
allow regulation of the largest stationary source emitters. ${ }^{84}$ These include new facilities with PTE of 100,000 tpy or more and modifications at existing facilities that increase GHG emissions by at least 75,000 tpy. ${ }^{85}$

Even assuming, arguendo, the statutory provisions under debate are not ambiguous, EPA claims that applying the statutory thresholds by their terms to GHG emissions would create absurd results. ${ }^{86}$ This is because PSD and Title V would then apply "to an extraordinarily large number" of "small" sources, the sources would incur "unduly high compliance costs," and permitting authorities would then face "overwhelming" administrative burdens. ${ }^{87}$ EPA claims such coverage would "severely undermine" congressional intent. ${ }^{88}$

The absurd results doctrine applies where "words of general meaning are used in a statute, and yet a consideration of the whole legislation, or of the circumstances surrounding its enactment, or of the absurd results which follow from giving such broad meaning to the words, makes it unreasonable to believe that the legislator intended to include the particular act." 89 Texas distinguishes EPA's interpretation of the CAA with the Supreme Court's decision in Green v. Bock Laundry Machine Co. ${ }^{90}$ In that decision, the Court construed the term " "the defendant' to exclude civil defendants, where refusing to draw that distinction would 'deny a civil plaintiff the same right to impeach an adversary's testimony that [the law] grants [to] a civil defendant.",91 Texas argues that while the term interpreted in Green was "broad," the statutory tonnage thresholds being interpreted by EPA are "objective commands that cannot be expanded or contracted through principles of statutory interpretation."

84. Douglas E. Schoen, Why Clean Energy Is the Key to America's Global Leadership, Fox NEws (Jan. 31, 2011), http://www.foxnews.com/opinion/2011/01/31/ clean-energy-key-americas-global-leadership/.

85. Final Tailoring Rule, supra note 3, at 31,516.

86. Bergeson, supra note 15; PSD Interpretive Memo, supra note 6, at 9.

87. Final Tailoring Rule, supra note 3, at 31,541; State of Texas' Motion for a Stay of EPA's Greenhouse Gas Tailoring Rule, supra note 24, at 9.

88. Final Tailoring Rule, supra note 3, at 31,542.

89. Holy Trinity Church v. United States, 143 US 457, 459 (1892).

90. State of Texas' Motion for a Stay of EPA's Greenhouse Gas Tailoring Rule, supra note 24 , at 10 .

91. Green, 490 U.S. at 510.

92. State of Texas' Motion for a Stay of EPA's Greenhouse Gas Tailoring Rule, supra note 24 , at $10-11$. 
The problem here is in making its argument, Texas failed to take notice of the case of United States $v$. Ron Pair Enterprises. ${ }^{93}$ In this case, the Supreme Court held that the literal meaning of a statutory provision is not conclusive "in the [] rare cases [in which] the literal application of a statute will produce a result demonstrably at odds with the intentions of the drafters[,] [in which case] the intention of the drafters, rather than the strict language, controls." 94 EPA interprets the legislative history of the CAA and the Court's holding in Ron Pair Enterprises to require that the Agency tailor the applicability criteria for GHGs so as "to balance environmental protection with economic growth." "5

One sound argument made against EPA's use of the absurd results doctrine comes from a member of the Unites States coal industry: Peabody Coal Company. ${ }^{96}$ The argument is that EPA does not identify a single case in which the doctrine was used to read out a numerical regulatory trigger for a particular situation within the purview of the statutory authority. ${ }^{97}$

Peabody Coal argues that the typical "absurd results" case is one where "a broad statutory term is interpreted more narrowly and in context in order to avoid a result that Congress could not have intended." 98 Such cases, in the opinion of Peabody Coal, are "unlikely to justify the [T]ailoring [R]ule because there is no narrower, contextual meaning of numerical terms" that EPA can use to achieve its desired statutory construction. ${ }^{99}$ These numerical terms, argues Peabody Coal, are different from the qualitative terms that the judiciary has ruled on earlier, such as "defendant," "employee," and "radioactive material."100

In a sense, the above argument is correct; it is impossible to argue that the terms " 100 " or " 250 " may be read as " 25,000 " based on some theory of statutory interpretation. However, this argument ignores a fundamental principle of the absurd results doctrine: The intention of the legislative drafters controls in cases in which the "literal application" of a statute produces results "demonstrably at odds with the intentions of the drafters." 101 Therefore, in this instance, what one must rely on are the

93. Final Tailoring Rule, supra note 3, at 31,542.

94. Id.; Ron Pair Enters., 489 U.S. at 242.

95. Frost Jr., et al., supra note 20.

96. Peabody Energy Co., Comments of Peabody Energy Company, Troutman SANDERS ATT'YS AT LAW 7 (Dec. 28, 2009), available at http://www.troutmansanders. com/files/uploads/documents/document.pdf.

97. Id.

98. Id. at $7-8$.

99. Id. at 8.

100. Id.

101. See Final Tailoring Rule, supra note 3, at 31,542; Ron Pair Enters., 489 U.S. at 242 . 
intentions of the drafters of the CAA rather than the seemingly unambiguous numerical trigger. ${ }^{102}$

Moreover, as one of the primary objectives within the legislative history of the CAA is "to balance environmental protection with economic growth," EPA's interpretation of this "balancing," under the doctrine of Chevron deference must be accorded great weight. ${ }^{103}$ Those who believe that EPA is acting outside of its authority claim that this is nothing more than EPA changing a number that it believes not to be workable after its inability to provide a "reasonable" construction of a statutory term in context. ${ }^{104}$ However, what EPA is doing is to rectify the policy of both PSD and Title V with the legislative history of the CAA "to balance environmental protection with economic growth."105 This action is consistent with the holding in Mova Pharm. Corp. v. Shalala. ${ }^{106}$ As the court in Shalala opined:

It is a familiar rule, that a thing may be within the letter of the statute and yet not within the statute, because not within its spirit nor within the intention of its makers .... . If a literal construction of the words of a statute be absurd, the act must be so construed as to avoid the absurdity. 107

Applying the Shalala holding to this instance, the Agency must, under Chevron Step One, select an interpretation that most closely approximates congressional intent. ${ }^{108}$

\section{a. Application of the Absurd Results Doctrine for the PSD Program}

As noted earlier, EPA's recent promulgation of LDVR triggered the applicability of the PSD program for stationary GHG-emitting sources at

102. Ron Pair Enters., 489 U.S. at 242.

103. Chevron, 467 U.S. at 842-43.

104. Peabody Energy Co., supra note 96, at 9.

105. Frost, Jr. et al., supra note 20.

106. Final Tailoring Rule, supra note 3, at 31,542; Mova Pharm. Corp. v. Shalala, 140 F.3d 1060, 1068-69 (DC Cir. 1998).

107. Mova Pharm. Corp., 140 F.3d at 1068; see also Holy Trinity Church, 143 U.S. at 459-60; U.S. v. X-Citement Video, Inc., 513 U.S. 64, 68-69 (1994) (rejecting the "most natural grammatical reading" of a statute to avoid "absurd" results); Green, 490 U.S. at 527-29 (Scalia, J., concurring); In re Nofziger, 925 F.2d 428, 434 (D.C. Cir. 1991); Dougherty, supra note 66.

108. Mova Pharm. Corp., 140 F.3d at 1068-69; see also Final Tailoring Rule, supra note 3 , at 31,541-46. 
the 100/250 tpy threshold levels as of January 2, 2011. ${ }^{109}$ PSD applicability hinges on the definition of "major emitting facility," a source that emits more than a certain amount of a pollutant as defined by EPA - an amount defined by EPA's New Source Performance Standards ("NSPS"). The major emitting facility, under EPA's long-standing narrowing interpretation and absent further tailoring, applies PSD requirements to sources of any air pollutant subject that is subject to regulation under the CAA. ${ }^{110}$ In this case, EPA's promulgation of LDVR means that emitters of GHGs became subject to regulation on the date the rule took effect, January 2, 2011. ${ }^{111}$

Absent tailoring, this trigger date would have subjected an extraordinarily large number of sources to regulation - the great majority of which would have been small commercial or residential sources. ${ }^{112}$ It is the belief of EPA that for many reasons, this result is contrary to congressional intent for the PSD program, and in fact would severely undermine what Congress sought to accomplish with the program. ${ }^{113}$ As a result, under the Chevron analysis, accounting for the absurd results doctrine, the statutory definition for "major emitting facility" should not be read to apply to all GHG sources at or above the 100/250 tpy threshold as of the trigger date. ${ }^{114}$ Instead, the definitions of "major emitting facility" and "modification" should be tailored so that they apply to GHG sources on a phased-in basis, regulating only the largest sources first. ${ }^{115}$

Chevron Step One calls for a determination of congressional intent, and courts consider the best indicator of congressional intent to be the plain meaning of the statute in question. ${ }^{116}$ However, the Supreme Court held in Ron Pair Enterprises that the literal meaning of a statute is not conclusive when the "literal application" of a statute produces results "demonstrably at odds with the intentions of the drafters." 117 To determine whether the intentions of the drafters differ from the result produced from "literal application" of the statutory provisions in question, courts may examine the overall context of the statutory provisions. ${ }^{118}$ This overall context includes whether there are related statutory provisions that either conflict or are consistent with that interpretation, and the

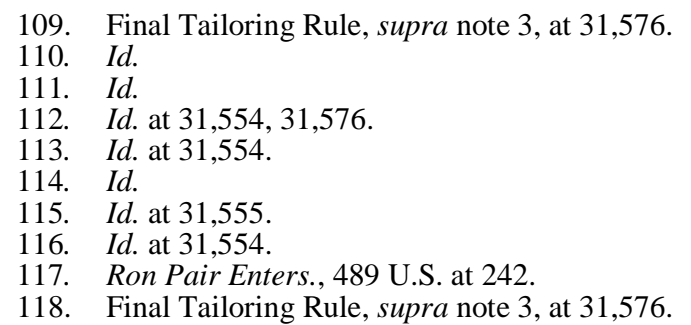


legislative history to see if it exposes what the legislature meant by the terms in question. ${ }^{119}$ In addition, courts may examine whether a literal application of the provisions produces a result that the courts characterize variously as "absurd, futile, strange, or indeterminate" and therefore so illogical or otherwise contrary to sensible public policy as to be beyond anything Congress would reasonably have intended. ${ }^{120}$ In such cases, the literal language cannot be said to reflect the intention of the drafters and therefore does not control. ${ }^{121}$ It is for such reasons that the Tailoring Rule is not only justified, but also necessary to comport with congressional intent.

Congress was keenly aware of the fact that the PSD program needed to serve dual purposes: to protect the environment and to promote economic growth. ${ }^{122}$ As such, Congress explicitly identified these goals in the "purposes" section of the PSD provision. ${ }^{123}$ For example, to protect economic growth, the PSD program expedites the permit process to include a 1-year limitation on the time that the permitting authority has to act on permit applications. ${ }^{124}$ To protect the environment, in addition to including many provisions that focus on pollutants regulated by National Ambient Air Quality Standards ("NAAQS"), the PSD program requires that the preconstruction permit impose emission limits that reflect BACT for each pollutant subject to regulation under another provision, CAA section 165(a)(4). ${ }^{125}$ This BACT provision also clarifies, by its terms, that although Congress designed the PSD program largely with NAAQS pollutants in mind, Congress also intended that sources subject to PSD control the emissions of their other pollutants as well. ${ }^{126}$ Moreover, the D.C. Circuit has recognized the twin goals of environmental protection and economic development that underlie PSD, and has upheld EPA interpretations of the PSD program that reflect a balancing of those goals. ${ }^{127}$

119. Id.

120. Id. at 31,554 .

121. Id. at 31,554-55; see Ron Pair Enters., 489 U.S. at 242-43; Griffin v. Oceanic Contractors, Inc., 458 U.S. 564, 571 (1982).

122. Final Tailoring Rule, supra note 3, at 31,555.

123. Id.

124. Id.

125. Id.

126. Id.

127. Id.; see, e.g., New York v. EPA, 413 F.3d 3, 27 (D.C. Cir. 2005), rehearing en banc den. 431 F.3d 801 (D.C. Cir. 2005). 
Congress paid careful attention to the types and sizes of sources that would be subject to the PSD program and designed the thresholds deliberately to limit the program's scope. ${ }^{128}$ This behavior is evident from the legislative history; several Senate floor statements and the Committee Report made clear that the PSD program should not apply to small sources. ${ }^{129}$ Within the legislative history, Senator Edmund Muskie ${ }^{130}$ stated that the Senate bill excluded from regulation "houses, dairies, farms, highways, hospitals, schools, grocery stores, and other such sources." 131 Senator James A. McClure ${ }^{132}$ stated that PSD provisions should be limited to "industrial plants of significant impact," and should exclude "[a] small gasoline jobber, or a heating plant at a community college, [which] could have the potential to emit 100 tons of pollution annually."133 The Senate Committee Report mirrored Senator McClure's statement, and concisely articulated the cost-related basis for the line drawing:

[The PSD] procedure ... must include an effective review-and-permit process. Such a process is reasonable and necessary for very large sources, such as new electrical generating plants or new steel mills. But the procedure would prove costly and potentially unreasonable if imposed on construction of storage facilities for a small gasoline jobber or on the construction of a new heating plant at a junior college, each of which may have the potential to emit 100 tons of pollution annually. 134

In 1980, the D.C. Circuit had occasion in Alabama Power, to acknowledge this legislative history. ${ }^{135}$ "Congress's intention was to identify facilities which, due to their size, are financially able to bear the substantial regulatory costs imposed by the PSD provisions and which, as a group, are primarily responsible for emissions of the deleterious pollutants that befoul our nation's air.”136 From the legislative history, it seems clear that Congress intended that PSD requirements be limited to a relatively small number of large industrial sources. ${ }^{137}$ Without any tailoring, the PSD program would expand from the current 280 sources

128. Final Tailoring Rule, supra note 3, at 31,555.

129. Id.

130. (D-ME) United States Senator from 1959 to 1980, Governor of Maine from 1955 and 1959, and Secretary of State under Jimmy Carter from 1980 to 1981.

131. 123 Cong. Rec. 18021 (June 8, 1977) (statement of Sen. Muskie); Final Tailoring Rule, supra note 3, at 31,555.

132. (R-ID) United States Senator from 1973 to 1991.

133. 122 Cong. REC. 24548-49 (July 29, 1976) (statement of Sen. McClure); Final

Tailoring Rule, supra note 3, at 31,555.

134. Final Tailoring Rule, supra note 3, at 31,555.

135. Alabama Power Co. v. Costle, 636 F.2d 323, 353; Final Tailoring Rule, supra note 3 , at 31,555 .

136. Final Tailoring Rule, supra note 3, at 31,555.

137. Id. 
per year to nearly 82,000 sources. ${ }^{138}$ More than $99 \%$ of such sources would be smaller than those currently in the PSD program and would be small commercial and residential sources. ${ }^{139}$

Besides the overly broad scope of the coverage, the total additional costs would be over $\$ 1.5$ billion, compared with $\$ 12$ million for the current PSD program. ${ }^{140}$ As illustrated above, this result would be contrary to the legislative history and Congress's careful efforts to confine PSD to large industrial sources. For these reasons, the absurd results doctrine must be applied to continue complying with the congressional intent of the PSD program.

\section{b. Application of the Absurd Results Doctrine for the Title V Program}

Due to the parallels between the PSD and Title V applicability provisions, much of the discussion concerning Title $\mathrm{V}$ mirrors the discussion of PSD above. Title $\mathrm{V}$ applicability provisions provide that after the effective date of the Title $\mathrm{V}$ program, it is unlawful for any person to operate a "major source" without a Title V permit. ${ }^{141}$ Under the current interpretation of Title $\mathrm{V}$, similar to the PSD applicability provisions, EPA's recent promulgation of LDVR triggered the applicability of Title $\mathrm{V}$ for GHG sources at the 100 tpy threshold levels as of January 2, 2011. ${ }^{142}$ Absent tailoring, the trigger date would have seen some 6.1 million sources become subject to Title V, an increase of over 400-fold of the previous number of sources subject to regulation. ${ }^{143}$

For many reasons, this result is contrary to congressional intent for the Title V program and would severely undermine what Congress sought to accomplish with the program. ${ }^{144}$ If Title $\mathrm{V}$ were compelled to apply to GHG sources at the 100 tpy level, all sources newly subject to Title V would need to apply for permits. ${ }^{145}$ Commercial and residential sources would incur, on average, expenses of $\$ 23,175$, while an industrial source would incur expenses of $\$ 46,350$, to prepare a permit application and

\footnotetext{
138. Id.

139. Id.

140. Id. at $31,557$.

141. Id. at 31,562 .

142. Id. at 31,577 .

143. Id.

144. Id. at 31,562 .

145. Id.
} 
receive a permit. ${ }^{146}$ The majority of these newly included sources would be small commercial and residential sources that Congress never intended to be included in Title V. ${ }^{147}$ For example, the legislative history of Title $\mathrm{V}$ indicated that Congress did not expect that "printers, furniture makers, dry cleaners, and millions of other small businesses" would become subject to Title V. ${ }^{148}$ These sources generally do not have the potential to emit criteria pollutants at or above the 100 tpy threshold. ${ }^{149}$ Yet, such sources would need to receive these costly permits as they carry a potential to emit GHGs above that threshold. ${ }^{150}$

The costs of this program to permitting authorities would be staggering. ${ }^{151}$ A permitting authority would expend an average of 214 hours, which according to EPA would cost $\$ 9,844$, to issue a permit to a commercial or residential source. ${ }^{152}$ These numbers would double to 428 hours and $\$ 19,688$, to issue a permit to an industrial source. ${ }^{153}$ In total, without tailoring, these permitting authorities would face over \$21 billion in additional permitting costs each year due to GHGs. ${ }^{154}$ This compares to the current program cost of $\$ 62$ million each year, less than one-third of one percent of the estimated cost under an untailored application of the program. ${ }^{155}$ EPA estimates that the permitting process would take longer than [ten] years to complete. ${ }^{156}$ "These delays would undermine the overall statutory design that promotes the smooth running of the permitting process and the underlying purpose of the Title $\mathrm{V}$ program itself." 157

After looking to Congress's careful efforts to confine these sources, such an outcome must be seen as an "absurd result." Accordingly, under Chevron, accounting for the absurd results doctrine, the statutory definition for "major source" could not have been intended to apply to all GHG sources at or above the 100 tpy threshold as of the trigger date. ${ }^{158}$ Therefore, the definition of "major source" must be tailored to

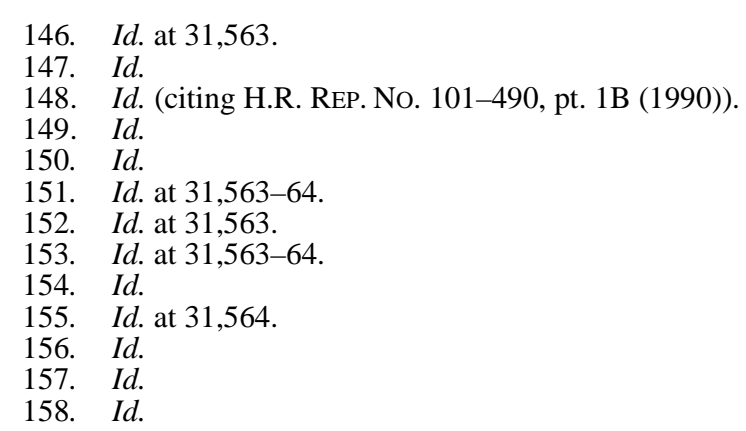


apply to GHG sources on a phased-in basis, with only the largest sources first. ${ }^{159}$ EPA's Tailoring Rule should stand.

\section{The Validity of EPA's Interpretation of the Administrative Necessity Doctrine}

Contrary to Texas's assertion, the administrative necessity doctrine receives support from and is the appropriate justification for EPA's departure from the unambiguous terms of the CAA. ${ }^{160}$ The D.C. Circuit provided its most robust expression of the administrative necessity doctrine in its 1980 decision, Alabama Power Co. v. Costle. ${ }^{161}$ In Alabama Power, the court resolved the challenges of industry and consumer groups to many aspects of the regulations that EPA promulgated soon after enactment of the 1977 CAA Amendments to implement the recently enacted statutory provisions. ${ }^{162}$ One regulatory provision intended to "exempt sources that qualified as major emitting facilities if their actual emissions were 50 tpy or less." 163 EPA sought to justify this provision under the auspices of administrative necessity because nearly 2,400 facilities emitted 50 tpy or less, believing the burdens of permit development and review would outweigh the small benefits of permitting. ${ }^{164}$ The court invalidated this regulatory exemption, stating it was not statutorily authorized; however, in so doing, the court recognized EPA's concerns about administrative burdens and articulated the basis for the administrative necessity doctrine. ${ }^{165}$

The court described the basis for the administrative necessity doctrine as "an overlay on clear statutory intent." 166 Specifically, the court held that "[c]ertain limited grounds for the creation of exemptions are inherent in the administrative process, and their unavailability under a

159. Id.

160. State of Texas' Motion for a Stay of EPA's Greenhouse Gas Tailoring Rule, supra note 24 , at $11-12$.

161. Proposed Tailoring Rule, supra note 73, at 55,312.

162. Id.

163. Id.

164. Id. at 55,312; Alabama Power Co., 636 F.2d at 323.

165. Proposed Tailoring Rule, supra note 73, at 55,312; see Alabama Power Co., 636 F.2d at 356-57. 357.

166. Final Tailoring Rule, supra note 3, at 31,556; Alabama Power Co., 636 F.2d at 
statutory scheme should not be presumed, save in the face of the most unambiguous demonstration of congressional intent to foreclose them."167

The Alabama Power court stressed the importance of ease of administration. Most importantly, the Court held that EPA, in interpreting the "modification" provisions that apply PSD to physical or operational changes by major emitting facilities that "increase the amount of any air pollutant emitted," may "exempt from PSD review some emission increases on grounds of de minimis or administrative necessity."168 The Court went on to state that in establishing the exemption thresholds, "[t]he Agency should look at the degree of administrative burden posed by enforcement at various de minimis threshold levels."169

Next, the court identified three types of administrative relief that may be available to an agency. ${ }^{170}$ The first is "[c]ategorical exemptions from the clear commands of a regulatory statute," which the court stated are "sometimes permitted," but "not favored." 171 The second is "an administrative approach not explicitly provided in the statute," such as "streamlined agency approaches or procedures where the conventional course, typically case-by-case determinations, would, as a practical matter, prevent the agency from carrying out the mission assigned to it by Congress." 172 The third type of administrative relief is a "delay of deadlines" upon "a showing by [the agency] that publication of some of the guidelines by that date is infeasible." "173 Finally, the court expounded upon the fact that it would assess "whether the agency faced an administrative impossibility and the acceptability of the agency's choices, based on the totality of the circumstances confronting the agency." 174 The court cautioned that "administrative necessity" is a difficult standard to achieve because "the agency [bears] a heavy burden to demonstrate the existence of an impossibility.","175

As in Alabama Power, the issue at hand is similarly situated. Both of these situations deal with the CAA and involve contested interpretations of statutory language. The court in Alabama Power also stressed the

167. Alabama Power Co., 636 F.2d at 357.

168. Id. at $400,405$.

169. Id.

170. Id. at 358-59.

171. Alabama Power Co., 636 F.2d at 358; Final Tailoring Rule, supra note 3, at 31,556.

172. Final Tailoring Rule, supra note 3, at 31,556.

173. Alabama Power Co., 636 F.2d at 359. See also Final Tailoring Rule, supra note 3 , at 31,563 (asserting that the literal application of Title V would make it infeasible for the agency to meet deadlines).

174. Alabama Power Co., 636 F.2d at 359. See also Final Tailoring Rule, supra note 3, at 31,563 (appealing for relief because the program would be otherwise "unadministrable").

175. Alabama Power Co., 636 F.2d at 359. 
importance of "administrability," a concept that plays a large role in the current situation as well. The Alabama Power court held that EPA, in interpreting the "modification" provisions that apply PSD to physical or operational changes by major emitting facilities that "increase the amount of any air pollutant emitted," 176 may "exempt from PSD review some emission increases on grounds of de minimis or administrative necessity." 177 However, the Court continued to state that in establishing the exemption thresholds, "the Agency should look at the degree of administrative burden posed by enforcement at various de minimis threshold levels." ${ }^{178}$ In these statements, the court not only provided credence for the doctrine of administrative necessity, but also for the exact application that EPA uses here for tailoring the provisions of the PSD program.

Absent tailoring, the January 2, 2011 trigger date for GHG PSD applicability would have seen some 6.1 million sources become subject to Title $\mathrm{V}$-an increase of over 400 -fold. ${ }^{179}$ The costs to the permitting authorities would also increase from $\$ 62$ million to $\$ 21$ billion, and the permitting authorities would need to hire, train, and manage 229,118 employees according to EPA estimates. ${ }^{180}$ Moreover, the overall cost to all 6.1 million sources would be $\$ 49$ billion per year over a 3-year period. ${ }^{181}$ Imposing burdens of this magnitude on these sources would be contrary to Congress's efforts to minimize the expenses of Title V, especially to small sources. ${ }^{182}$ Similarly, absent tailoring, the total additional costs would be over $\$ 1.5$ billion for the current PSD program, compared with $\$ 12$ million presently. ${ }^{183}$ The PSD program would expand from the current 280 sources per year to nearly 82,000 sources. ${ }^{184}$ More than $99 \%$ of such sources would be smaller than those currently in the PSD program and would be small commercial and residential sources. ${ }^{185}$

176. Id. at 400; Final Tailoring Rule, supra note 3, at 31,563 (quoting Clean Air Act $\S 111(\mathrm{a})(4)(2011))$.

177. Final Tailoring Rule, supra note 3, at 31,563.

178. Id.

179. Id. at 31,577 .

180. Id.

181. Id. at 31,563 .

182. Id.

183. Id. at 31,557 .

184. Id.

185. Id. 
Essentially, the situation that would emerge from a literal application of the PSD and Title V programs to all GHG sources would almost certainly beget both multi-year delays in issuance of all permits and exorbitant costs to permitting authorities as well as to sources. ${ }^{186}$ This literal interpretation would apply PSD and Title V to millions of sources that Congress did not expect to be covered, and the ensuing administrative burdens would impede the issuance of permits to the thousands of sources that Congress did expect to be covered. ${ }^{187}$ The sheer magnitude of the numbers involved clearly indicates that the result of a literal application of the PSD and Title V provisions to GHG sources cannot be what Congress intended and must therefore be covered by the administrative necessity doctrine. Most importantly, it appears quite certain that EPA has met the "heavy burden" in demonstrating "the existence of an impossibility" that the court spoke about in Alabama Power.

\section{CONCLUSION}

This Comment addressed a number of legal arguments submitted by states and industry advocates that are legally insufficient to overrule the regulations made by EPA and the deference accorded to EPA's interpretations in light of the Chevron ruling. The most important reason why applying the PSD and Title V programs to GHG sources without tailoring would be inconsistent with congressional intent is that the resulting program would prove administratively impossible. Aside from the staggering costs that would be added to these programs and the sources therein regulated, adding over 6.1 million permit applications to the less than 15,000 that currently exist would overwhelm permitting authorities and for all practical purposes would bring the permitting process to a standstill. ${ }^{188}$

The Tailoring Rule symbolizes a number of complex legal issues. This Comment does not seek to resolve each of these individual issues. However, this Comment does strive to analyze the legal arguments of each side in this debate concerning the doctrines of administrative necessity and absurd results. In doing so, it seems that the deference afforded by Chevron gives EPA more than sufficient juridical credence to ensure that EPA will prevail.

As stated by the Supreme Court in 2009, the interpretation applied by EPA governs "if it is a reasonable interpretation of the statute-not

\footnotetext{
186. Id. at 31,564 .

187. Id.

188. Id. at 31,540 .
} 
necessarily the only possible... interpretation, nor even the interpretation deemed most reasonable by the courts." 189 Certainly, EPA's interpretation is not the only possible interpretation. However, in the present instance, it seems most difficult to argue that the interpretation of EPA is not "a reasonable interpretation of the statute." In light of Chevron, administrative deference to agency decision-making receives a great amount of weight, and the administrative burdens that would be placed on these sources and permitting agencies would be insurmountable. For these reasons, EPA will be successful in any of the legal arguments challenging the validity of EPA's use of the administrative necessity and absurd results doctrines. Consequently, the judiciary should validate EPA's use of these doctrines in its fashioning of the Tailoring Rule.

189. Entergy Corp. v. Riverkeeper, Inc., 129 S.Ct. 1498, 1505 (2009). 